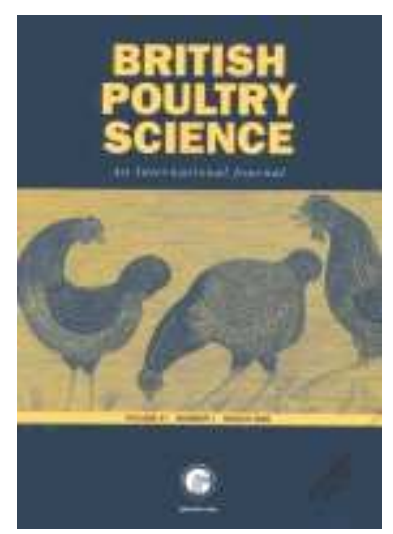

\title{
Carcass characteristics and qualitative meat traits of three Italian local chicken breeds
}

\begin{tabular}{|r|l|}
\hline Journal: & British Poultry Science \\
\hline Manuscript ID: & CBPS-2009-258.R1 \\
\hline Manuscript Type: & Original Manuscript \\
\hline Author: & 08-Jan-2010 \\
\hline Complete List of Authors: & $\begin{array}{l}\text { Zanetti, Enrico; University od Padova, Animal Science } \\
\text { De Marchi, Massimo; University of Padova, Animal Science } \\
\text { Dalvit, Chiara; University od Padova, Animal Science } \\
\text { MOLETTE, Caroline; ENSAT, Zootechnie et Qualite des Produits } \\
\text { Animaux } \\
\text { Remignon, Herve; INPT, ENSAT-Animal Sciences; ENSAT, } \\
\text { Zootechnie et Qualite des Produits Animaux } \\
\text { Cassandro, Martino; University od Padova, Animal Science }\end{array}$ \\
\hline Keywords: & Meat quality, Carcass characteristics, Local chicken breeds \\
\hline \multicolumn{2}{|l}{} \\
\hline
\end{tabular}

\section{SCHOLARONE \\ Manuscripts}


4 Carcase characteristics and qualitative meat traits of three Italian local 5 chicken breeds

6 E. ZANETTI, M. DE MARCHI, C. DALVIT, C. MOLETTE ${ }^{1,2}$, H. REMIGNON ${ }^{2,3}$ AND M. 7 CASSANDRO 8

9 Department of Animal Science, University of Padova, Viale dell'Università 16, 35020 10 Legnaro, Padova, Italy, ${ }^{1}$ INRA, Castanet-Tolosan, France, ${ }^{2}$ Université de Toulouse, France 11 and ${ }^{3}$ ENVT, Toulouse, France

12 13 14 15 16 17 18 19 20 21 22 23 24 25 26

Correspondence to: Dr M. De Marchi, Department of Animal Science, University of 28 Padova, Viale dell'Università 16, 35020 Legnaro, Padova, Italy.

29 E-mail: massimo.demarchi@unipd.it 30 31 32
Running title: Meat quality of local chicken 
33 Abstract 1. An experiment involving 60 male chickens reared in an organic production system 34 was carried out in order to investigate carcase characteristics and qualitative meat traits of three slow-growing Italian local breeds of chicken (Ermellinata, Padovana and Pépoi).

2. Chicks were randomly selected at hatch, raised together under the same conditions, slaughtered at $190 \mathrm{~d}$ of age, dissected for carcase traits, and meat (breast and thigh) stored for subsequent analysis of quality parameters.

39 3. Ermellinata chickens were significantly different from Padovana and Pépoi chickens for live, 40 carcase and thigh weights. Breeds were also different for breast muscle protein content 41 (Ermellinata > Pépoi and Padovana), shear force (Padovana < Ermellinata and Pépoi) and cooking loss (Pépoi > Padovana and Ermellinata) values.

43 4. The CIE system values of lightness $\left(\mathrm{L}^{*}\right)$, redness $\left(\mathrm{a}^{*}\right)$, and yellowness $\left(\mathrm{b}^{*}\right)$ evidenced a 44 distinctive darker meat and lighter skin colour of Padovana breast meat.

5. Polyunsaturated fatty acids composition of breast meat was similar among the analysed 46 breeds. Ermellinata had significantly higher saturated but significantly lower monounsaturated fatty acid contents than the other two breeds.

\section{INTRODUCTION}

Consumer interest is growing in specialty poultry products, particularly in Europe. Examples 50 exist in France, with 'Label Rouge' (Westgren, 1999) and Poulet de Bresse, and in Italy with 51 Padovana chicken (De Marchi et al., 2005). Production systems require extensive rearing 52 conditions with outdoor access. Despite a higher retail price than conventional poultry 53 products, these types of chicken have aroused lively interest in national markets (Westgren, 54 1999; Fanatico and Born, 2001). In Italy, among those slow-growing genotypes there are 55 several local chicken breeds that showed interesting meat quality traits (e.g. colour and 56 flavour) (De Marchi et al., 2006a). Fast-growing meat strains of chicken are characterised by 57 a very low degree of adaptation and resistance to natural environment (Reiter and Bessei, 58 1996); in contrast, the slow-growing strains can fully benefit from organic system (pasture 59 availability, older age). Several studies have investigated differences in the sensory quality of 60 meat from fast- and slow-growing birds, but there was a wide variation in breed (purebred, 61 broiler or layer), slaughter age and production system (standard, extensive or organic) 62 (Touraille et al., 1981; Brown et al., 2008; Jaturasitha et al., 2008; Sandercock et al., 2009). 63 This has produced contrasting results regarding consumer preference and acceptance, but 64 reports have generally been more favorable for slower-growing birds than conventional 65 products. 
In the Veneto region of Italy, the increasing interest in the conservation of bovine, ovine and poultry local breeds (De Marchi et al., 2006a,b; Dalvit et al., 2008, 2009; Zanetti et al., 2010) is due to historical, social and economical reasons. A few breeds of chicken, Padovana (PA), Ermellinata (EA), and Pépoi (PI), which are typically reared in extensive systems, provide interesting alternatives to commercial broilers. The recent development of organic animal production and consumer requests for food safety and sustainable systems of production might encourage the use of local chicken breeds for several niche markets. Previous research has been focused on the carcase characteristics and quality meat traits of the Padovana breed of chicken (De Marchi et al., 2005) because it has been in great demand.

The interest in local genotypes has increased noticeably in the last decade, mostly because biodiversity conservation and management has become an important issue for the international scientific community (Fao, 2007). Productive performance analysis and phenotypic traits, together with genetic diversity, reproductive and adaptative performances, and historical interest, are therefore highly relevant to the inclusion of local breeds in conservation programmes (Ruane, 1999).

The objective of this research was to describe carcase characteristics and qualitative meat traits of three local Italian chicken breeds at maturity, as well as at a light, medium or heavy body weight.

\section{MATERIALS AND METHODS}

\section{Animals, diets and experimental procedures}

A trial was conducted at the Duca degli Abruzzi Agricultural High School in Padova. Three slow-growing genotypes were compared, Pépoi (PI), Padovana (PA) and Ermellinata (EA), and categorised according to the weight they reached at $190 \mathrm{~d}$ (market weight): PI had a live weight of $1400-1600 \mathrm{~g}$, PA a live weight of 2000 - $2200 \mathrm{~g}$ and EA a live weight of 2800 3000 g (De Marchi et al., 2006a). Twenty 30-d male birds were obtained from each breed and housed together in an indoor pen $\left(5 \mathrm{birds} / \mathrm{m}^{2}\right)$ which had access to a grass paddock (4 $\mathrm{m}^{2} /$ bird $)$. All birds were provided with a grower diet $(210 \mathrm{~g} \mathrm{CP} / \mathrm{kg}, 50 \mathrm{~g} / \mathrm{kg}$ lipids, $40 \mathrm{~g} / \mathrm{kg}$ fibre, $70 \mathrm{~g} / \mathrm{kg}$ ash, and $13.39 \mathrm{MJ} \mathrm{ME} / \mathrm{kg}$ ) from $2 \mathrm{~d}$ before the trial commenced until slaughter at $190 \mathrm{~d}$. Ingredients for the grower diet were maize flour, toasted soybean meal, maize gluten meal, maize gluten, soybean oil, dicalcium phosphate, calcium carbonate, sodium chloride and DL-methionine. Feed and water were supplied ad libitum. The diets were crumbled vegetable diet without animal products, antibiotics or coccidiostats. A total of 60 birds (20 males for each breed) were slaughtered at $190 \mathrm{~d}$ of age. Feed was withdrawn $18 \mathrm{~h}$ prior to slaughter, and the birds weighed, electronically stunned, plucked and eviscerated. 
100 The carcases were cooled in a tunnel, refrigerated at $4^{\circ} \mathrm{C}$ for $24 \mathrm{~h}$ and weighed. The breast 101 and thigh meat from all chickens were then harvested and processed for meat quality 102 parameters determination. Other breast meat samples were also collected and stored at $-20^{\circ} \mathrm{C}$ 103 for further analyses.

\section{Analytical determinations}

105 Breast (Pectoralis superficialis) and thigh (Peroneus longus) muscle $\mathrm{pH}$ were measured $24 \mathrm{~h}$ 106 post-mortem using a Delta Ohm HI-8314 pH-meter (Delta Ohm, Padova Italy). Colour, 107 tenderness and cooking loss were also determined $24 \mathrm{~h}$ post-mortem. Colour parameters were 108 measured using a Minolta CM-508c (illuminate: D65, observer: $10^{\circ}$ ) on thigh and breast skin 109 and on breast meat. Breast meat colour was taken immediately after skin removal. Readings 110 were performed at the same anatomical positions for all breast and thigh samples. For each 111 sample, three measurements were performed and the final value for each chicken was the 112 average of those readings. Skin colour of breast and thigh and meat colour of breast were 113 expressed in the CIELab colour space by reporting $L^{*}, a^{*}$ and $b^{*}$ values (CIE, 1978).

114 Cooking loss percentage (CL\%), expressed as the ratio of the weight before and after 115 cooking, was measured on the left part of the breast muscle without the skin using 2-cm thick 116 samples sealed in a polyethylene bag and heated in a water bath to an internal temperature of $11770^{\circ} \mathrm{C}$ for $40 \mathrm{~min}$ (ASPA, 1996). Shear force (SF) on breast muscle was measured on 5 118 cylindrical cores, $1.13 \mathrm{~cm}$ in diameter and taken parallel to muscle fibres, using a TA-HDi 119 Texture Analyser (Stable Macro System, London, Great Britain) with a Warner-Bratzler shear 120 attachment (10 N load cell, crosshead speed of $2 \mathrm{~mm} / \mathrm{s})$ and interpreted using texture expert 121 software (ASPA, 1996).

122 All chemical analyses were performed on the right breast, without skin, and were in 123 accordance with AOAC (1990) standards. Moisture was determined after drying at $102^{\circ} \mathrm{C}$ for $12416 \mathrm{~h}$, ash was determined after mineralisation at $525^{\circ} \mathrm{C}$ for $6 \mathrm{~h}$ and total lipids analysed by 125 extraction with petroleum ether (Soxhlet method). Protein content was estimated by 126 difference. For the determination of total fatty acids composition, lipids were extracted 127 according to the method of Folch et al. (1957). A 5-g homogenised meat sample was blended 128 twice with extraction solvent chloroform/methanol $(1: 2, \mathrm{v} / \mathrm{v})$, filtered, placed in separator 129 funnels and mixed with saline solution $(0.88 \% \mathrm{KCl})$. After separation in two phases, the 130 methanol aqueous fraction was discarded and the lipid chloroform fraction washed with 131 distilled water/methanol (1:1, v/v). Following a further filtration and evaporation in a rotary 132 evaporator, lipid extracts were prepared for trans-esterification in n-Heptane according by

133 Christie (1982) and transferred to test tubes for subsequent gas chromatographic analysis, 
134 which was conducted on a Thermo Quest (model 8000 Series Top, Milan, Italy) instrument 135 equipped with a Omegawax 250 capillary column (length $30 \mathrm{~m}$, internal diameter $0.25 \mathrm{~mm}$, 136 Supelco, Bellafonte, PA, USA).

\section{Statistical analysis}

138 Data were subjected to ANOVA by the GLM procedure considering breed as a fixed effect 139 using SAS $^{\circledR}$ software (1997, SAS Institute, Cary, NC). For breed effect, a multiple 140 comparison of means was performed using the Bonferroni's test $(P<0.05)$.

\section{RESULTS}

142 The least square means of carcase composition, $\mathrm{pH}$ values, breast chemical composition, 143 shear force and cooking loss values are shown in Table 1. Final live weights of the three 144 breeds at $190 \mathrm{~d}$ of age (just before slaughter) were significantly different. Ermellinata had 145 heavier live, carcase and thigh weights than PA and PI, while PI had lighter breast weight 146 than PA and EA. Breast weight and total dressing did not differ statistically for PA and EA, 147 while the incidence of breast on carcase weight was similar for PA and PI. Dressing 148 percentage was greater for PA and EA than PI, while PA and PI had greater breast percentage 149 than EA.

Table 1 near here

150 Dry matter, protein and lipid contents of the breast muscle differed only slightly 151 among breeds (Table 1). Maximum shear force values for PA birds, as measured on cooked 152 breast muscle, were significantly different from the other breeds (Table 1). The pH values 153 measured in the breast muscle were significantly higher for PA than the other two breeds, 154 while, the thigh $\mathrm{pH}$ of PI birds had the highest values. The PA breed showed the highest 155 tenderness followed by EA and PI, while cooking loss values were higher for PI breed relative 156 to PA and EA birds. Tables 2 \& 3 near here

157 Breast and thigh colour values are shown in Table 2. PA breed showed a significantly 158 higher $\mathrm{L}^{*}$ value of breast skin than PI or EA, while the PI showed significantly lower $\mathrm{a}^{*}$ and $159 \mathrm{~b}^{*}$ values than PA or EA. The $\mathrm{L}^{*}$ value of thigh skin for PI was significantly higher than 160 either PA or EA, a* indices were not significantly different for the three breeds, while the $b^{*}$ 161 index was significantly higher for EA than either PI or PA. The breast meat colour for PA had 162 a significantly lower $\mathrm{L}^{*}$ value than for EA or PI, while EA b* values were significantly lower 163 than PA or PI.

164 Raw breast meat (without the skin) fatty acid compositions are shown in Table 3. 165 Ermellinata breed had a significantly higher content of saturated (SFA) but lower amount of 166 monounsaturated (MUFA) fatty acids than either PA or PI. There were no significant 167 differences between breeds for n-3 and n-6 polyunsaturated fatty acids. Ermellinata differed 
168 from the other breeds because of a higher $\mathrm{C}_{16: 0}$ content and a lower production of $\mathrm{C}_{18: 1 \text { cis n-9 }}$ and

$169 \mathrm{C}_{18: 2 \mathrm{cis} \text { n-6 }}$ fatty acids (Table 4). There were no significant differences in DPA nor CLA fatty

170 acids among breeds but PI breast meat had a significantly higher content of DHA than PA.

Table 4

DISCUSSION

near here

171

172

173

174

175

176

177

178

179

180

181

182

183

184

185

186

187

188

189

190

191

192

193

194

195

196

197

198

199

200

201

The EA, PA and PI chickens exhibited medium, light and very light carcase weights respectively. The dressing and breast percentages of PA were slightly lower than those reported for the same breed by De Marchi et al. (2005). Dressing percentages for PA, EA and PI breeds were also slightly lower than those reported for local Thai chicken genotypes (Jasurasitha et al., 2008) and markedly lower than that reported for commercial broilers (Havenstein et al., 2003; Cortinas et al., 2004). These results indicate that the Italian local chicken breeds have relatively low carcase weights, and inferior dressing and breast percentages to other meat-type genotypes.

Contrastingly, the $\mathrm{pH}$ values were higher than expected; possible reasons are slaughter stress and a higher content of oxidative muscle fibre in other common slow-growing genotypes (Dransfield and Sosnicki, 1999). Regarding the first hypothesis, it is likely that the old unselected breeds have a more aggressive and alert behaviour than the modern broilers (Jaturasitha et al., 2004; Debut et al., 2005); this higher sensibility to the stressful conditions before slaughter can lead to poor glycogen content in muscle at the time of death. However, no other information is available concerning muscle fibre analysis for these breeds. Nevertheless, the breast $\mathrm{pH}$ values of the PA breed were lower than those reported previously by De Marchi $e t$ al. (2005) for the PA breed.

Dry matter, protein and lipid contents of the breast muscles differed slightly among breeds. The chemical composition of the PA breed breast was consistent with values reported by De Marchi et al. (2005). The dry matter and protein contents of these three local Italian breeds were similar to those reported for other organic chickens (Castellini et al., 1994; Castellini et al., 2002). In contrast, protein, lipids and ash contents were higher for the Italian local breeds than for Thai indigenous chickens or normal commercial broilers (Wattanachant et al., 2004). As expected, local chicken muscle contains a high proportion of protein and low fat and ash contents, which agrees with previously reported findings from Wattanachant et al. (2005). The PA and EA breeds showed a greater cooking loss compared with the values reported by De Marchi et al. (2005) and Rizzi et al. (2007).

Low $\mathrm{L}^{*}$ values are associated to a higher ultimate $\mathrm{pH}$ value because of the weak light scattering in high-pH chicken meat (Swatland, 2008). The darker breast muscle of the PA breed can thus reflect differences in the muscle fibre composition and in the glycogen content 
202 of the muscle. For this reason, the analysis of breast meat $\mathrm{L}^{*}$ values were also conducted 203 using the fixed effect of breed and the effect of $\mathrm{pH}$ as co-variate. In the preliminary analysis, 204 the interaction between breed and $\mathrm{pH}$ was not significant. Furthermore, the PA had the lowest 205 L* value of breast meat.

The fatty acid composition of the breast meat in this study was similar to that reported 207 by De Marchi et al. (2005) and Castellini et al. (2006) for Ross 205 and Kabir chickens reared 208 in an organic rearing system. The observed differences in SFA and MUFA among the three 209 breeds in this study can be attributed only to their genetic make-up, because diets and rearing 210 system were identical for all breeds throughout the experimental period. Even the highest 211 saturated fatty acid contents of the EA breed were still lower than those reported for organic 212 (38\%) and Thai local chickens (62\%) (Wattanachant et al., 2004). Among SFA, palmitic 213 (C16:0) and stearic (C18:0) acids were the most abundant, as generally observed in chicken 214 breast meat.

215 In conclusion, the study demonstrated significant differences in meat quality traits 216 among the three breeds studied, for example in carcase yield, colour, tenderness and fatty acid 217 composition. From a consumer point of view, each breed offers unique features. Besides a 218 greater traditional interest and a high historical and cultural value, the tenderness of the PA meat 219 and its distinctively darker colour differentiated it from the other breeds. In contrast, none of the 220 meat quality traits of EA and PI showed the meat of these breeds to be significantly distinctive 221 from other meat-type genotypes. Additionally, adaptability features, traits of scientific and 222 economic interests, cultural historical value, strong links to local traditions and its ability to 223 generate incomes from tourism justify the efforts for their conservation and characterisation 224 (Ruane, 1999). The commercialisation and capitalisation of local markets represent an 225 opportunity for future added value and development of these local genetic resources. 226 Alternative strategies, such as the use of crosses of these breeds with more productive 227 commercial breeds, are currently under evaluation to enhance their use for niche and regional 228 markets.

\section{REFERENCES}

230 AOAC (1990) Official Methods of Analysis (15th ed.). Association of Official Analytical 231 Chemists. Washington, DC.

232 ASPA (1996) Associazione Scientifica di Produzione Animale, Metodiche per la 233 determinazione delle caratteristiche qualitative della carne, Università degli studi di Perugia. 
234 BROWN, S.N., NUTE, G.R., BAKER, A., HUGHES, S.I. \& WARRISS, P.D. (2008) Aspects 235 of meat and eating quality of broiler chickens reared under standard, maize-fed, free-range or 236 organic systems. British Poultry Science, 49:118-124.

237 CASTEllini, C., DAL BOSCO, A., MUGNAI, C. \& PEDRAZZOLI, M. (2006) Comparison 238 of two chicken genotypes organically reared: oxidative stability and other qualitative traits of 239 the meat. Italian Journal Animal Science, 5: 355-368.

240 CASTEllini, C., MUGNAI, C. \& DAL BOSCO, A. (2002) Effect of organic production 241 system on broiler carcass and meat quality. Meat Science, 60: 219-225.

242 CASTELlini, C., PANNELLA, F. \& LATTAIOLI, P. (1994) Impiego della razza Ancona per 243 l'impiego di un pollastro di qualità. Rivista di Avicoltura, 5: 1-45.

244 CHRISTIE, W.W. (1982) A simple procedure for rapid transmethylation of glycerolipids and 245 cholesterol ester. Journal of Lipid Research, 23: 1072-1075.

246 CIE (1978) International Commission on Illumination, recommendations on uniform color 247 spaces, color, difference equations, psychometric color terms. CIE publication No. 15 (Suppl. 248 2), (E-1.31) 1971/(TC-1.3). Bureau Central de la CIE, Paris, France.

249 CORTINAS, L., VILLAVERDE, C., GALOBART, J., BAUCELLS, M.D., CODONY, R. \& 250 BARROETA, A.C. (2004) Fatty acid content in chicken thigh and breast as affected by 251 dietary polyunsaturation level. Poultry Science, 83: 1155-1164.

252 DALVIT, C., DE MARCHI, DAL ZOTTO, R., ZANETTI. E., MEUWISSENM. M. \& 253 CASSANDRO, M. (2008) Genetic characterization of the Burlina cattle breed using 254 microsatellites markers. Journal of Animal Breeding and Genetics, 125: 137-144.

255 DALVIT, C., DE MARCHI, ZANETTI. E. \& CASSANDRO, M. (2009) Genetic variation 256 and population structure of Italian native sheep breeds undergoing in situ conservation. 257 Journal of Animal Science, 87: 3837-3844.

258 DE MARCHI, M., CASSANDRO, M., LUNARDI, E., BALDAN, G. \& SIEGEL, P.B. (2005) 259 Carcass characteristics and qualitative meat traits of the Padovana breed of chicken. 260 International Journal of Poultry Science, 4: 233-238.

261 DE MARCHI, M., CASSANDRO, M., TARGHETTA, C., BARUCHELLO, M. \& NOTTER, 262 D.R. (2006a) Conservation of poultry genetic resource in the Veneto region of Italy. Animal 263 Genetic Resources Information (FAO/UNEP), 37: 63-74.

264 DE MARCHI, M., DALVIT, C., TARGHETTA, C., \& Cassandro, M. (2006b). Assessing 265 genetic diversity in the indigenous Veneto chicken breeds using AFLP markers. Journal of 266 Animal Genetics, 37: 101-105. 
267 DEBUT, M., BERRI, C., ARNOULD, C., GUEMENÉ, D., SANTÉ-LHOUTELLIER, V., 268 SELLIER, N., BAÉZA, E., JEHL, N., JÉGO, Y., BEAUMONT, C. \& LE BIHAN-DUVAL, E. 269 (2005) Behavioural and physiological responses of three chicken breeds to pre-slaughter 270 shackling and acute heat stress. British Poultry Science, 46: 527- 35.

271 DRANSFIELD, E. \& SOSNICKI, A.A. (1999) Relationship Between Muscle Growth and 272 Poultry Meat Quality. Poultry Science, 78: 743-746.

273 FANATICO, A.C. \& BORN, H. M. (2001) Label Rouge: Pastureraised poultry in France. 274 ATTRA publication. National Center Appropriate Technology, Fayetteville, AR.

275 FAO (2007). The state of the world's animal genetic resources for food and agriculture. 276 Commission on genetic resources for food and agriculture. Food and Agriculture 277 Organization of the United Nations. Rome.

278 FOLCH, J., LEES, M. \& SLOANE-STANLEY, H. (1957) A simple method for the isolation 279 and purification of total lipids from animal tissue. Journal of Biological Chemistry, 226: $497-$ 280509.

281 HAVENSTEIN, G.B., FERKET, P.R. \& QURESHI, M.A. (2003) Carcass composition and 282 yield of 1957 versus 2001 broilers when fed representative 1957 and 2001 broiler diets. 283 Poultry Science, 82: 1509-1518.

284 JATURASITHA, S., KHIAOSAARD, R., PONGPAEW, A., LEAWTHARAKUL, A., 285 SAITONG, S., APICHATSARANGKUL, T. \& LEAUNGWUNTA, V. (2004) Carcass and 286 indirect meat quality of native and Kai Baan Thai chickens with different sex and slaughter 287 weight. In: Proceedings 42nd Annual Conference Kasetsart University, Bangkok, Thailand, 288 pp. 116-126.

289 JATURASITHA, S., SRIKANCHAI, T., KREUZER, M. \& WICKE, M. (2008) Differences in 290 Carcass and Meat Characteristics Between Chicken Indigenous to Northern Thailand (Black291 Boned and Thai Native) and Imported Extensive Breeds (Bresse and Rhode Island Red). 292 Poultry Science, 87: 160-169.

293 REITER, K. \& BESSEI, W. (1996) Effect of the distance between feeder and drinker on 294 behaviour and leg disorders of broilers. In Proceedings of 30th Intnational Congress of 295 Applied Ethology, Guelph, Canada, p. 131

296 RIZZI, C, MARANGON, A \& CHIERICATO, G.M. (2007) Effect of Genotype on 297 Slaughtering Performance and Meat Physical and Sensory Characteristics of Organic Laying 298 Hens. Poultry Science, 86: 128-135 
299 RUANE, J. (1999) Selecting breeds for conservation, in: OLDENBROEK, J.K. (Ed) 300 Genebanks and the conservation of farm animal genetic resources, pp. 59-73 (The 301 Netherlands, DLO Institute for Animal Science and Health).

302 SANDERCOCK, D. A., NUTE, G. R. \& HOCKING, P. M. (2009) Quantifying the effects of 303 genetic selection and genetic variation for body size, carcass composition, and meat quality in 304 the domestic fowl (Gallus domesticus). Poultry Science, 88: 923-931.

305 SAS Institute, (1997) SAS/STAT® User's Guide: Statistics, Version 6.12, SAS Institute Inc., 306 Cary, NC.

307 SWATLAND, H.J. (2008) How pH causes paleness or darkness in chicken breast meat. Meat 308 Science, 80: 396-400.

309 TOURAILlE, C., KOPP, J., VALIN, C. \& RICARD, F.H. (1981) Chicken meat quality. 1. 310 Influence of age and growth rate on physicochemical and sensory characteristics of the meat. 311 Archiv für Geflügelkunde, 45: 69-76.

312 WATTANACHANT S., BENJAKUL, S. \& LEDWARD, D.A., (2005) Microstructure and 313 Thermal Characteristics of Thai Indigenous and Broiler Chicken Muscles. Poultry Science, 84: 314 328-336.

315 WATtANACHANT, S., BENJAKUL, S. \& LEDWARD, D.A. (2004) Composition, Color, 316 and Texture of Thai Indigenous and Broiler Chicken Muscles. Poultry Science, 83: 123-128.

317 WESTGREN, R.E. (1999) Delivering food safety, food quality, and sustainable production 318 practices: The Label Rouge Poultry System in France. American Journal of Agricultural 319 Economics, 81: 1107-1111.

320 ZANETTI, E., DE MARCHI, M., DALVIT, C., \& CASSANDRO, M. (2010). Genetic 321 Characterization of Local Italian Breeds of Chickens Undergoing In-Situ Conservation. 322 Poultry Science, 89: 420-427. 323 
Table 1. Least square means of carcase composition, $p H$ values, breast chemical composition, shear force and cooking loss values of Ermellinata, Padovana and Pépoi slowgrowing chicken at 190 d of age

\begin{tabular}{lccccc}
\hline & \multicolumn{3}{c}{ Breed } & \multirow{2}{*}{ Res MS } \\
\cline { 2 - 4 } & Padovana & Ermellinata & Pèpoi & & \\
\hline - Live weight (LW), g & $2144^{\mathrm{b}}$ & $2718^{\mathrm{a}}$ & $1434^{\mathrm{c}}$ & 0.89 & 187 \\
- Carcase weight (CW), g & $1346^{\mathrm{b}}$ & $1726^{\mathrm{a}}$ & $879^{\mathrm{c}}$ & 0.88 & 125 \\
- Breast weight (BW), g & $225^{\mathrm{a}}$ & $243^{\mathrm{a}}$ & $140^{\mathrm{b}}$ & 0.72 & 29 \\
- Thigh weight (TW), g & $478^{\mathrm{b}}$ & $667^{\mathrm{a}}$ & $322^{\mathrm{c}}$ & 0.89 & 50 \\
Dressing (CW/LW), \% & $63^{\mathrm{a}}$ & $64^{\mathrm{a}}$ & $61^{\mathrm{b}}$ & 0.27 & 1.59 \\
Breast (BW/CW), \% & $17^{\mathrm{a}}$ & $14^{\mathrm{b}}$ & $16^{\mathrm{a}}$ & 0.27 & 1.88 \\
Thigh (TW/CW), \% & $35^{\mathrm{c}}$ & $38^{\mathrm{a}}$ & $36^{\mathrm{b}}$ & 0.39 & 1.60 \\
Breast meat pH & $6.18^{\mathrm{a}}$ & $5.97^{\mathrm{b}}$ & $5.99^{\mathrm{b}}$ & 0.21 & 0.18 \\
Thigh meat pH & $6.19^{\mathrm{b}}$ & $6.15^{\mathrm{b}}$ & $6.30^{\mathrm{a}}$ & 0.16 & 0.15 \\
Breast muscle chemical composition & & & & & \\
- Dry matter (\%) & $24.85^{\mathrm{b}}$ & $26.18^{\mathrm{a}}$ & $25.45^{\mathrm{ab}}$ & 0.26 & 0.95 \\
- Total proteins (\%) & $23.23^{\mathrm{b}}$ & $24.65^{\mathrm{a}}$ & $23.89^{\mathrm{b}}$ & 0.11 & 0.79 \\
- Total lipids (\%) & $0.61^{\mathrm{a}}$ & $0.29^{\mathrm{b}}$ & $0.48^{\mathrm{ab}}$ & 0.37 & 0.28 \\
- Ash (\%) & 1.08 & 1.12 & 1.10 & 0.20 & 0.05 \\
Shear Force (N) & $12.51^{\mathrm{a}}$ & $16.76^{\mathrm{b}}$ & $15.84^{\mathrm{b}}$ & 0.19 & 3.82 \\
Cooking loss (\%) & $18.20^{\mathrm{b}}$ & $19.31^{\mathrm{b}}$ & $22.34^{\mathrm{a}}$ & 0.29 & 2.81 \\
\hline
\end{tabular}
$327 \quad{ }^{\mathrm{a}, \mathrm{b}, \mathrm{c}}$ Within a row, means not sharing a common superscript are significantly different at $P$ 328 $<0.05$. 
329 Table 2. Breast and thigh colour values of Ermellinata, Padovana and Pépoi slow-growing 330 chicken at 190 d of age.

\begin{tabular}{|c|c|c|c|c|c|}
\hline \multirow{2}{*}{ Item } & \multicolumn{3}{|c|}{ Breed } & \multirow{2}{*}{$\mathrm{r}^{2}$} & \multirow{2}{*}{ Res MS } \\
\hline & Padovana & Ermellinata & Pepoì & & \\
\hline
\end{tabular}

Skin colour Breast

- L*

$-a^{*}$

$-b^{*}$

$62.41^{\mathrm{a}}$

$56.96^{\mathrm{b}}$

$59.20^{\mathrm{b}}$

0.32

3.27

$-2.15^{\mathrm{a}}$

$-2.42^{\mathrm{a}}$

$-3.07^{\mathrm{b}}$

0.25

0.69

Thigh

- L*

$1.91^{\mathrm{a}}$

$1.06^{\mathrm{a}}$

$-1.47^{b}$

0.21

2.84

$-a^{*}$

$62.08^{\mathrm{b}}$

$62.35^{\mathrm{b}}$

$63.81^{\mathrm{a}}$

0.15

1.89

$-b^{*}$

$-2.19$

$-1.99$

$-2.47$

0.08

0.69

Meat colour

$-1.97^{\mathrm{c}}$

$3.94^{\mathrm{a}}$

$0.01^{\mathrm{b}}$

0.62

1.94

Breast

- L*

$46.00^{\mathrm{a}}$

$48.41^{\mathrm{b}}$

$49.84^{\mathrm{b}}$

0.35

2.38

- a*

$-1.72$

$-1.39$

0.11

0.42

$-b^{*}$

$-0.45^{\mathrm{a}}$

$-1.64^{\mathrm{b}}$

$0.04^{\mathrm{a}}$

0.14

1.75

$P<0.05$. 
Table 3. Least square means of raw breast (without skin) fatty acid composition of Ermellinata, Padovana and Pépoi slow-growing chicken at $190 \mathrm{~d}$ of age

\begin{tabular}{lccccc}
\hline & \multicolumn{3}{c}{ Breed } & \multirow{2}{*}{$\mathrm{r}^{2}$} & \multirow{2}{*}{ Res MS } \\
\cline { 2 - 4 } & Padovana & Ermellinata & Pépoi & & \\
\hline Breast muscle & \multicolumn{2}{c}{$\%$ of total } & analysed fatty & acid \\
Total SFA & $33.88^{\mathrm{b}}$ & $35.59^{\mathrm{a}}$ & $32.82^{\mathrm{b}}$ & 0.46 & 1.29 \\
Total MUFA & $23.45^{\mathrm{a}}$ & $20.21^{\mathrm{b}}$ & $24.92^{\mathrm{a}}$ & 0.39 & 2.55 \\
Total PUFA & 40.24 & 41.38 & 40.09 & 0.05 & 2.71 \\
Total n-6 FA & 36.63 & 37.74 & 36.23 & 0.08 & 2.27 \\
Total n-3 FA & 3.60 & 3.64 & 3.85 & 0.02 & 0.73 \\
n-6/n-3 & 10.51 & 10.93 & 9.66 & 0.06 & 2.19 \\
\hline
\end{tabular}

${ }^{\mathrm{a}, \mathrm{b}}$ Within a row, means not sharing a common superscript are significantly different at $P<0.05$.

SFA: saturated fatty acid; MUFA: monounsaturated fatty acid; PUFA: polyunsaturated fatty acid; FA: fatty acid. 
Table 4. Least square means of raw breast (without skin) detailed fatty acid composition of Ermellinata, Padovana and Pépoi slow-growing chicken at $190 \mathrm{~d}$ of age

\begin{tabular}{|c|c|c|c|c|c|}
\hline \multirow{2}{*}{ Fatty acid } & \multicolumn{3}{|c|}{ Breed } & \multirow{2}{*}{$\mathrm{r}^{2}$} & \multirow{2}{*}{ Res MS } \\
\hline & Padovana & Ermellinata & Pépoi & & \\
\hline Breast muscle & \multicolumn{3}{|c|}{$\%$ of total analysed fatty acid } & & \\
\hline C6:0 & 0.02 & 0.02 & 0.01 & 0.18 & 0.02 \\
\hline $\mathrm{C} 8: 0$ & $0.06^{\mathrm{b}}$ & $0.10^{\mathrm{a}}$ & $0.11^{\mathrm{a}}$ & 0.40 & 0.03 \\
\hline C10:0 & 0.06 & 0.08 & 0.07 & 0.08 & 0.02 \\
\hline C12:0 & 0.03 & 0.02 & 0.02 & 0.08 & 0.02 \\
\hline $\mathrm{C} 14: 0$ & $0.44^{\mathrm{a}}$ & $0.29^{\mathrm{b}}$ & $0.28^{\mathrm{b}}$ & 0.28 & 0.12 \\
\hline $\mathrm{C} 15: 0$ & 0.09 & 0.08 & 0.07 & 0.08 & 0.02 \\
\hline $\mathrm{C} 16: 0$ & $20.65^{\mathrm{a}}$ & $21.40^{\mathrm{a}}$ & $19.50^{\mathrm{b}}$ & 0.34 & 1.13 \\
\hline $\mathrm{C} 17: 0$ & $0.28^{\mathrm{a}}$ & $0.25^{\mathrm{ab}}$ & $0.24^{\mathrm{b}}$ & 0.16 & 0.04 \\
\hline C18:0 & $11.51^{\mathrm{b}}$ & $12.64^{\mathrm{a}}$ & $11.86^{\mathrm{b}}$ & 0.27 & 0.81 \\
\hline C20:0 & $0.08^{\mathrm{ab}}$ & $0.06^{\mathrm{b}}$ & $0.09^{\mathrm{a}}$ & 0.15 & 0.04 \\
\hline C21:0 & 0.01 & 0.01 & 0.01 & 0.10 & 0.01 \\
\hline $\mathrm{C} 22: 0$ & $0.01^{\mathrm{b}}$ & $0.01^{\mathrm{b}}$ & $0.02^{\mathrm{a}}$ & 0.21 & 0.02 \\
\hline C10:1 n-1 & 0.05 & 0.04 & 0.04 & 0.05 & 0.02 \\
\hline $\mathrm{C} 14: 1 \mathrm{n}-1$ & 0.01 & 0.01 & 0.01 & 0.01 & 0.01 \\
\hline C16:1 n-9 & 0.20 & 0.16 & 0.18 & 0.09 & 0.05 \\
\hline C16:1 n-7 & 0.39 & 0.34 & 0.46 & 0.08 & 0.17 \\
\hline C17:1 n-9 & 0.03 & 0.07 & 0.11 & 0.09 & 0.10 \\
\hline $\mathrm{C} 17: 1 \mathrm{n}-7$ & $0.01^{\mathrm{b}}$ & $0.01^{\mathrm{ab}}$ & $0.02^{\mathrm{a}}$ & 0.38 & 0.01 \\
\hline $\mathrm{C} 18: 1 \mathrm{n}-7$ trans & 0.04 & 0.03 & 0.02 & 0.13 & 0.02 \\
\hline C18:1 n-9 trans & $0.01^{\mathrm{b}}$ & $0.02^{\mathrm{ab}}$ & $0.02^{\mathrm{a}}$ & 0.17 & 0.01 \\
\hline $\mathrm{C} 18: 1 \mathrm{n}-9$ cis & $20.69^{\mathrm{a}}$ & $17.79^{\mathrm{b}}$ & $21.53^{\mathrm{a}}$ & 0.33 & 2.38 \\
\hline $\mathrm{C} 18: 1 \mathrm{n}-7 \mathrm{cis}$ & $1.73^{\mathrm{b}}$ & $1.46^{\mathrm{c}}$ & $2.18^{\mathrm{a}}$ & 0.68 & 0.21 \\
\hline C20:1 n-9 & $0.19^{\mathrm{a}}$ & $0.13^{b}$ & $0.22^{\mathrm{a}}$ & 0.34 & 0.05 \\
\hline $\mathrm{C} 18: 2 \mathrm{n}-6$ trans & 0.01 & 0.01 & 0.01 & 0.04 & 0.01 \\
\hline $\mathrm{C} 18: 2 \mathrm{n}-6$ cis & $25.25^{\mathrm{a}}$ & $21.79^{b}$ & $21.84^{\mathrm{b}}$ & 0.18 & 3.52 \\
\hline C18:3 n-6 & $0.08^{\mathrm{a}}$ & $0.04^{\mathrm{b}}$ & $0.05^{\mathrm{b}}$ & 0.32 & 0.03 \\
\hline C18:3n-3 & $0.93^{\mathrm{a}}$ & $0.56^{\mathrm{b}}$ & $0.61^{b}$ & 0.26 & 0.28 \\
\hline CLA & 0.01 & 0.01 & 0.01 & 0.06 & 0.01 \\
\hline$C 20: 2 n-6$ & $0.45^{\mathrm{a}}$ & $0.39^{\mathrm{b}}$ & $0.43^{\mathrm{ab}}$ & 0.15 & 0.05 \\
\hline C20:3 n-6 cis & $0.41^{\mathrm{b}}$ & $0.73^{\mathrm{a}}$ & $0.54^{\mathrm{b}}$ & 0.43 & 0.16 \\
\hline$C 20: 4 n-6$ & $9.06^{\mathrm{b}}$ & $13.11^{\mathrm{a}}$ & $11.78^{\mathrm{ab}}$ & 0.19 & 3.64 \\
\hline $\mathrm{C} 22: 1 \mathrm{n}-9$ cis & 0.01 & 0.01 & 0.01 & 0.03 & 0.01 \\
\hline $\mathrm{C} 20: 5 \mathrm{n}-3$ cis & 0.06 & 0.05 & 0.08 & 0.03 & 0.06 \\
\hline$C 22: 2 n-6$ & 0.17 & 0.29 & 0.22 & 0.10 & 0.16 \\
\hline$C 22: 4 n-6$ & 0.01 & 0.03 & 0.01 & 0.14 & 0.04 \\
\hline$C 22: 5 n-6$ & 1.19 & 1.33 & 1.36 & 0.04 & 0.34 \\
\hline $\mathrm{C} 24: 1 \mathrm{n}-9$ cis & 0.30 & 0.29 & 0.34 & 0.02 & 0.13 \\
\hline C22:5 n-3 DPA & 1.19 & 1.37 & 1.26 & 0.04 & 0.41 \\
\hline C22:6 n-3 DHA & $1.42^{\mathrm{b}}$ & $1.66^{\mathrm{ab}}$ & $1.90^{\mathrm{a}}$ & 0.13 & 0.53 \\
\hline
\end{tabular}

